\begin{tabular}{cc} 
Araştırma Makalesi / Research Article & Harran Tarım ve Gıda \\
Geliş tarihi: 29.04.2016 & 20(3): 192-203 \\
\hline
\end{tabular}

\title{
Farklı Kurutma Teknikleri ve Ön İşlem Uygulamaları ile Kurutulmuş Soğanların Rehidrasyon Kapasitelerinin Artırılması
}

\author{
Mehmet KARAASLAN ${ }^{1}$, Ali YILDIRIM ${ }^{1 *}$, Hasan VARDiN ${ }^{1}$ \\ ${ }^{1}$ Harran Üniversitesi, Ziraat Fakültesi, Gıda Mühendisliği Bölümü, Osmanbey Kampüsü, Şanlıurfa \\ *Sorumlu yazar: ayildirim10@gmail.com
}

Öz

Rehidrasyon kapasitelerinin artırılması amacıyla dilimlenmiş ve ön işlem uygulanmış soğanlar açıkta, vakumda, fırında, güneş enerjili kurutucularda ve dondurarak kurutma yöntemleriyle kurutulmuşlardır. Ayrıca, kurutma denemeleri öncesinde dilimlenmiş soğanlara malto dekstrin, patates nişastası ve tuz çözeltilerine daldırılarak ön işlem uygulamaları yapılmıştır. Yapılan denemeler sonucunda güneş enerjili kurutucuda kurutulan soğanlarda rehidrasyon kapasitesi $5.74 \pm 0.70$ 'e, açıkta kurutulan soğanlarda $5.36 \pm 0.30$ 'e, kabin kurutucuda kurutulan soğanlarda $5.94 \pm 0.40$ 'e, vakum kurutucuda kurutulan soğanlarda $6.69 \pm 0.70$ 'ye ve dondurarak kurutucuda kurutulan soğanlarda ise $7.94 \pm 0.50$ 'e çıktığı tespit edilmiştir. Bu sonuçlara bağlı olarak farklı ön işlem uygulamaları ve farklı kurutucu sistemlerinin uygulanması ile rehidrasyon kapasitesinde önemli artışlar sağlanabileceği belirlenmiştir.

Anahtar kelimeler: Soğan, Rehidrasyon kapasitesi, Kurutma, Renk

\section{Improvement of Rehdyration Capacity of Dried Onions by Using Different Dehydration Techniques and Pre-treatment Applications}

\begin{abstract}
The sliced onions were processed using different drying methods such as open air, cabinet, vacuum, freeze, solar drying after pre-treatments. The onions were soaked into potato starch, maltodextrin, salt solutions for pretreatment applications. According to obtained results the rehydration capacity improved to $5.74 \pm 0.70$ in the solar dried samples, to $5.36 \pm 0.30$ in the open air dried samples, to $5.94 \pm 0.40$ in the cabinet dried samples, to $6.69 \pm 0.70$ in the vacuum dried samples and to $7.94 \pm 0.50$ in the freeze dried samples. These results suggested that it is possible to improve rehydration capacity of the samples by using different various pretreatment applications and drying methods.
\end{abstract}

Keywords: Onion, Rehydration capacity, Drying, Color

\section{Giriş}

Türkiye, Çin, Hindistan ve USA gibi ülkelerle beraber dünyanın önde gelen soğan üreticisi ülkelerindendir (Kumar ve Tiwari, 2007; Arslan ve Özcan, 2010). Amasya, Bursa, Gaziantep ve Güneydoğu Anadolu bölgesi ülkemizde soğan tarımının yaygın olarak yapıldığı yörelerdir. Kuru soğan üretimi ve ihracatı ülkemizin önemli tarımsal faaliyet alanları arasındadır (Anonim, 2016). Ancak gelişen dünya ekonomisi içerisinde hammadde üreten ülkelerin ötesinde hammadde işleyerek katma değerli ürün üreten ülkeler ekonomi yarışında öne geçmektedir. Bu 
nedenle, ülkemizde soğana yeni değerlendirilme şekilleri katarak yurt içi ve yurt dışı satış değerlerini artırmak büyük önem arz etmektedir. Bu kapsamda kurutulmuş soğan üretiminin teşvik edilmesi ile yurt içi ve dışı pazarlara ulaşılarak bu ürüne katma değer kazandırmak ülke ekonomimize büyük katkılar sağlayacaktır. Bunun sağlanabilmesi için de daha kaliteli talep gören ürünler üretmek temel zorunluluktur.

Kurutulmuş soğan, çorba, sos, sosis vb bir çok hazır gıdaya tat vermek amacı ile depolama ve kullanım kolaylığından dolayı taze soğandan daha fazla tercih edilmektedir (Mota ve ark, 2010; Kaymak-Ertekin ve Gedik, 2005; Rapusas ve Driscoll, 1995). Özellikle mutfak kültürü gelişmiş ve refah seviyesi yüksek Avrupa ülkelerinden talep görmektedir. Ancak ihraç edilecek ürünlerin belirli standartlara ve kalite özelliklerine sahip olması gerekmektedir. Kurutulmuş soğan özelinde düşünüldüğünde son ürünün koyu olmayan parlak renge, kabul edilebilir besinsel içeriğe ve en önemlisi yüksek rehidrasyon kapasitesine sahip olması gerekmektedir (Mitra ve ark., 2011). Kurutulmuş soğanda görülen en önemli problem rehidrasyon kapasitesinin düşük olmasıdır. Bu problem nedeniyle kurutulmuş soğanlar düşük rakamlarla fiyatlandırılmakta ve işletmelerin karlılığını olumsuz etkilemektedir. Kaliteli kurutulmuş soğan üretiminde en önemli kıstas olan rehidrasyon yeteneğinin artırılması ile ürünün ekonomik değeri yükseltilerek yurt içi ve yurt dışında talep artışı sağlanabileceği araştırıcılar tarafından öne sürülmektedir. Bu amaçla çalışma kapsamında kurutulmuş soğanlarda farklı ön işlem uygulamaları ve farklı kurutma yöntemleri kullanılarak rehidrasyon kapasitesinin artırılması hedeflenmiştir.

\section{Materyal ve Metot}

\section{Bitki materyali ve soğanların kurutulması}

Çalışmada kullanılan Yalova-12 tipi soğanlar Gaziantep-Sakçagözü yöresinden temin edilmiş ve laboratuvara taşınarak kurutma işlemleri yapılıncaya kadar uygun şartlarda bekletilmişlerdir. Soğanlar ayıklandıktan, temizlendikten ve kabukları soyulduktan sonra 1-3 mm kalınlığında olacak şekilde doğranmış ve tek tabaka haline getirilip bir kontrol ve dört ayrı ön işlem uygulanarak 5 farklı sistemde kurutulmuştur. İstenilen yüzey alanı sağlanan soğanlara suda bekletme, patates nişastasına daldırma, tuzlu suda bekletme, maltodekstrin çözeltisine daldırma ön işlemleri uygulanmıştır. Dilimlenmiş ve tabakalarından ayrılmış soğanlar 250 g olacak şekilde 4 ayrı kaba alınmış önceden hazırlanmış olan 500 ml'lik çözeltiler (\%5 (w/w) patates nişastası, $\% 5(\mathrm{w} / \mathrm{w})$ tuzlu su, $\% 5(\mathrm{w} / \mathrm{w})$ maltodekstrin ve çeşme suyu) 1:2 oranında soğanların üzerine ilave edilmiş ve oda sıcaklığında yarım saat bekletilmiştir. Yarım saatin sonunda örneklerin hepsi ayrı ayrı süzülerek filtre kâğıtları üzerine serilmiş ve sonrasında kurutuculara yerleştirilmiştir.

Ön işlem uygulanan soğanlar kabinde, açıkta, vakumda, güneş enerjili kurutucularda ve dondurarak kurutulmuşlardır. Dondurarak kurutma işleminde diğer kurutma sistemlerinden farklı olarak soğanlara ön işlem uygulandıktan sonra $-20{ }^{\circ} \mathrm{C}$ 'de dondurucuda 2 saat bekletilmiş ve ürünler donmuş halde kurutucuya yerleştirilmiştir. $\mathrm{Bu}$ çalışma kapsamında ilk olarak kurutma işleminde kullanılacak olan soğanların genel kimyasal analizleri $(\mathrm{pH}$, kuru madde, çözünür kuru madde, kül tayini, titrasyon asitliği) yapılmıştır. Kurutulan örneklerin ilk olarak kurutma verimleri ve rehidrasyon kapasiteleri 
ölçülmüştür ve ardından örneklerin renk, su aktivitesi ve duyusal değerlendirilmeleri aşağıda açıklandığı şekilde tayin edilmiştir. Analizler 3 tekrarlı olarak, oda şartlarında $\left(24^{\circ} \mathrm{C}\right)$ yapılmıştır.

\section{pH analizi}

Kurutulmuş soğanlar laboratuvar tipi bir blenderda parçalanarak analize hazır hale getirilmiş̧ir. Elde edilen örnek bir bez yardımı ile süzülerek alınan soğan suyunda pH ölçümü masa tipi $\mathrm{pH}$ metre (Orion 420) kullanılarak yapılmıştır (AOAC, 1985).

\section{Titrasyon asitliği}

Laboratuvar tipi blenderda parçalanarak elde edilen soğan suyundan $10 \mathrm{ml}$ alınarak 2 damla fenolftaleyn indikatörü damlatılarak 0.10 $\mathrm{N} \mathrm{NaOH}$ ile $\mathrm{pH} 8.10$ olana kadar titre edilmiştir. Sonuç sitrik asit cinsinden ifade edilmiştir (AOAC, 1985).

\section{Kül tayini}

Krozeler $105{ }^{\circ} C^{\prime}$ de yarım saat kendi ağırlığına gelinceye kadar etüvde bekletildikten sonra desikatöre alınıp soğutularak hassas terazide darası belirlenmiştir. Krozeye 4-5 gr örnek tartılarak $550^{\circ} \mathrm{C}^{\prime}$ ye ayarlanan kül fırınına yerleştirilmiştir. Yakma işlemi sonunda sabit tartıma gelen krozelerde kül miktarı (\% g/g) belirlenmiştir (AOAC, 1985).

\section{Çözünür kuru madde tayini}

Soğan suyunda suda çözünür kuru madde miktarı masa tipi Abbe refraktometresi (Atago marka) ile doğrudan yüzde olarak belirlenmiştir (Gould, 1977).

\section{Kurutulmuş soğanlarda nem tayini \\ Soğanlarda nem tayini AOAC 934.01 metodu ile hesaplanmıştır. Bu metoda göre}

partiküllerine ayrılmış olan örneklerden $2 \mathrm{~g}$ tartılarak vakum fırınında (Binder, Almanya) $105^{\circ} \mathrm{C}^{\prime}$ de $100 \mathrm{mmHg}$ basınç altında 5 saat kurutulmuştur (AOAC, 2000).

Su aktivitesi tayini

Su aktivitesi değeri enstrümental olarak su aktivitesi cihazı (Hygropalm AW1; Rotronic, Basserdorf, i̇sviçre) ile doğrudan belirlenmiştir.

\section{Renk analizi}

Soğanlarda ve kurutma işlemi uygulanmış soğanlarda Hunter Lab kolorimetresi kullanılarak $L^{*}, a^{*}, b^{*}$ değerleri hesaplanarak renk değerlendirmesi yapıldı. Elde edilen $L^{*}$ değeri parlaklık, a* değeri kırmızılık, b* değeri sarı rengi ifade etmektedir (Roldan-Marin ve ark.,2009).

\section{Kurutma verimi}

Kurutma verimi aşağıdaki formüle göre yüzde (\%) olarak hesaplanmıştır.

$$
\operatorname{Verim}(\%)=\frac{\operatorname{son} \text { ağırllk }(\mathrm{kg})}{i l k \text { ağ } \mathrm{rlllk}(\mathrm{kg})} * 100
$$

\section{Rehidrasyon kapasitesinin ölçümü}

Rehidrasyon kapasitesinin ölçümü Lewicki ve Witrowa-Rajchert (1998) tarafından açıklanan yönteme göre yapılmıştır. Kurutma işlemi sonrasında elde edilen örneklerden $1 \mathrm{~g}$ alınarak bir behere konulmuş ve üzerine $100 \mathrm{~mL}$ saf su eklenmiştir. Rehidrasyon işlemi 0.5, 1, 2, $3,4,5$ saat boyunca devam edilerek ve belirtilen süreler sonunda örnekler bir filtre kağıdı üzerinde bekletilerek dış kısımlarındaki (absorbe edilmeyen) nem uzaklaştırılmış ve tartım işlemi yapılmıştır. 


\section{Duyusal analiz}

Duyusal değerlendirmede ürünler Renk, Gevreklik, Koku, Lezzet ve Genel İzlenim gibi özellikleri bakımından değerlendirmeye tabi tutulmuştur. Duyusal analizler Altuğ (1993)'e göre dört temel tada duyarlılıkları test edilmiş 10 kişilik bir panelist grubu tarafından yapılmıştır. Panelistlerin değerlendirmelerinde; 1-3(çok kötü-kabul edilemez), 4-5(orta), 67(iyi), 8-9(çok iyi) puan aralığındaki hedonik skala kullanılmıştır (Amerine, ve ark.,1965).

\section{Araştırma Bulguları ve Tartışma}

Bitkisel ürünlerde titrasyon asitliği ürünün olgunluk derecesinin belirlenmesinde önemli bir ölçüttür. Gıdalarda renk, tat, tekstür ve hoş koku oluşumu üzerinde etkilerini belirlemek amacıyla titrasyon asitliği değeri sitrik asit cinsinden tayin edilmiştir. Yalova-12 soğan çeşidinde ölçülen titrasyon asitliği değeri ortalama $2.436 \times 10^{-3} \mathrm{~g} \mathrm{ml}^{-1}$ olarak tespit edilmiştir. Gıdalarda mikrobiyal stabilite için sahip olduğu kül miktarı önemlidir. Çünkü yüksek mineral konsantrasyonu mikroorganizma gelişmesini geciktirebilir. Beslenme açısından da olumlu bir kalite özelliğidir. Yalova-12 soğan çeşidinde ölçülen kül miktarı \%0.60 (w/w) olarak tespit edilmiştir. Türk Gıda Kodeksi verilerine göre soğanda toplam kül miktarı en çok $\% 5(\mathrm{w} / \mathrm{w})$ olması istenir. Elde ettiğimiz değerin standartlarda belirtilen değerlere uygun olduğu tespit edilmiştir. Soğanlarda briks ölçümü ürünün olgunluğunu ve hasat zamanını belirlemek amacıyla yapılır. Yalova-12 soğan çeşidinde briks değeri \%14.50 (w/w) olarak tayin edilmiştir ve soğanların işlemeye uygun olgunlukta olduğunu göstermiştir (Çizelge 1).
Çizelge 1. Denemelerde kullanılan Yalova-12 soğan çeşidinin bazı fiziko-kimyasal özellikleri

Table 1.Some physico-chemical properties of Yalova-12 onion variety used in experiment

\begin{tabular}{lr}
\hline $\begin{array}{l}\text { Özellik } \\
\text { Property }\end{array}$ & $\begin{array}{r}\text { Değer } \\
\text { Value }\end{array}$ \\
\hline $\mathrm{pH}$ & $5.20 \pm 0.01$ \\
$\mathrm{pH}$ & \\
Asitlik $\left(\mathrm{g} \mathrm{m}^{-1}\right)$ & \\
$($ sitrik asit cinsinden) & \\
Asidity $\left(\mathrm{g} \mathrm{m}^{-1}\right)$ (citric acid) & $0.60 \pm 0.05$ \\
Kül (\% w/w) & \\
Ash $(\% \mathrm{w} / \mathrm{w})$ & $14.50 \pm 0.10$ \\
ÇKM (\% w/w) & \\
Soluble solids (\% w/w) & \\
\hline
\end{tabular}

Kurutulmuş soğanların nem değişimi

Kurutmada temel amaç en az maliyetle ürüne en az zararı vererek en fazla suyu uzaklaştırmaktır (Vardin ve Binici, 2006) . Çizelge 2'de görüldüğü gibi işlenmemiş soğanların nem oranları \%85.92-\%89.25 (w/w) değerleri arasında yer alırken kurutma işlemi gerçekleştikten sonra bu oran \%8.00$\% 10.00(w / w)$ 'a kadar düşmüştür. Çizelge 2' de örnek olarak çeşitli ön işlemler uygulanmış olan soğanların kabin kurutucuda kurutulduktan sonra sahip oldukları nem oranları verilmiştir. Diğer metotlarla kurutulan soğanlarda da nem oranı \%8.00-\%10.00 (w/w) seviyelerine indirilerek stabil ürünler elde edilmiştir (Çizelge 2). Böylece soğanların depolama şartlarına dayanıklılığı arttırılarak yurt dışına taşınmaya uygun hale getirilmiştir. 
Çizelge 2. Soğanların kurutma öncesi ve kabinde kurutma sonrası nem oranları

Table 2. Moisture ratio of onions before and

\begin{tabular}{lcc}
\multicolumn{3}{c}{ after drying in cabinet dryer } \\
\hline $\begin{array}{l}\text { Ön Işlemler } \\
\text { Pre-treatments }\end{array}$ & $\begin{array}{c}\text { Kurutma } \\
\text { Öncesi Nem } \\
(\%)\end{array}$ & $\begin{array}{c}\text { Kurutma } \\
\text { Sonrası Nem } \\
(\%)\end{array}$ \\
& $\begin{array}{c}\text { Moisture } \\
\text { before drying }\end{array}$ & $\begin{array}{c}\text { Moisture after } \\
\text { drying }\end{array}$ \\
\hline Önişlem & 86.50 & 8.90 \\
uygulanmamış & & \\
Tuzlu su & 86.50 & 9.90 \\
Çeşme suyu & 89.10 & 9.40 \\
Patates nişastası & 87.60 & 8.70 \\
Maltodekstrin & 88.30 & 10.20 \\
\hline
\end{tabular}

Kurutulmuş soğanlarda su aktivitesi değişimi

Kurutulmuş ürünlerin raf ömrünün arttırılmasında su aktivitesi çok önemli bir kıstastır. Bu değerin düşük olması ürünün raf ömrünü uzatır. Bir gıdadaki bileşim öğelerinin kimyasal reaksiyona girme hızı ve bu gıdada gelişen mikrobiyal aktivite doğrudan su aktivitesi tarafından kontrol edilmektedir (Scott, 1957). Yalova-12 soğan çeşidinde başlangıçta ölçülen su aktivitesi değerlerinin 0.83 - 0.94 arasında iken kurutma işleminden sonra su aktivitesi $0.205-0.397$ değerleri arasına düşürülmüştür. Su aktivitesi değeri kurutulmuş ürünlerin dayanımını belirleyen en önemli kıstaslardandır ve su aktivitesi düşük gıdalar mikrobiyal gelişim ve enzimatik faaliyet açısından güvenli olarak kabul edilir. Genel olarak bu çalışma sonucunda elde edilen tüm örneklerde su aktivitesi değerlerinin güvenli sınırlara çekildiği tespit edilmiştir.

\section{Kurutulmuş soğanlarda renk değişimi}

Tüketicilerin kaliteli gıda algısını belirleyen en önemli faktörlerden birisi ürünün sahip olduğu doğal parlak rengidir. L* değeri parlaklığı ifade etmekte olup, 0-100 arasında değerler almaktadır. Siyahı 0 değeri, beyazı 100 değeri gösterir (Mc Guire, 1992).

Tüm diğer kurutulmuş ürünlerde olduğu gibi kurutulmuş soğanlarda da ürün renginin soğanın doğal rengine mümkün olduğunca benzer olması istenir. Bu renk kriterini sağlamak için $L^{*}$ (parlaklık) değerinin yüksek ve $b^{*}$ (sarı) değerinin düşük olması istenir. Dondurarak kurutulan örneklerde; $L^{*}$ değerinin $83.00 \pm 2.00$, $b^{*}$ değerinin ise $13.00 \pm 1.00$ olduğu tespit edilmiş̧ir. Açıkta kurutulan soğanlarda; L* değeri $65.00 \pm 3, b^{*}$ değeri ise $25.00 \pm 20$ olarak ölçülmüştür. Bunların yanı sıra vakum kurutucuda kurutulan örneklerde $L^{*}$ değeri $70.00 \pm 30, b^{*}$ değeri ise $17.00 \pm 2.00$; güneş enerjili sistemde $L^{*}$ değeri $63.00 \pm 20, b^{*}$ değeri $28.00 \pm 20$; kabin kurutucuda işlenen soğanlarda $L^{*}$ değeri $72.00 \pm 2.00$ ve $b^{*}$ değeri $23.00 \pm 2.00$ olarak tayin edilmiştir. Gökçe ve ark. (2010) tarafından yapılan bir çalışmada Karbeyazı çeşidi soğanın $L^{*}$ değerinin $69.10 \pm 3.70$ olduğu tespit edilmiştir. Bu ve diğer araştırmacıların (Gökçe ve ark., 2010) elde ettiği sonuçlarla bizim çalışmamız kapsamında ölçülen $L^{*}$ değerleri arasında çok yakın benzerlik gözlenmiştir.

Kurutucu performanslarını ürünün rengi açısından değerlendirecek olursak en iyi sonucun dondurularak kurutulmuş olan örneklerde elde edildiği açıktır. Bu örneklerde $L^{*}$ değeri diğerlerine göre daha yüksekken; $b^{*}$ sarılık değerleri de oldukça düşük olarak kaliteli bir kurutma işlemine işaret etmektedir. Diğer tüm kurutma tiplerinde de değerlerin birbirine göre çok yakın olduğu tespit edilmiştir. Özellikle güneş enerjili sistem, kabin ve vakum kurutucularda maltodekstrin ön işlemi uygulanan soğanlarda önemli renk değişiklikleri gözlenmiştir. 


\section{Kurutma verimi}

Endüstriyel bir kurutma tesisinin karlılığını belirleyen temel kriter işlenen ürünlerden elde edilen kurutma verimidir ve beklenildiği üzere yüksek verim yüksek kazanca işaret etmektedir (Vardin ve Binici, 2006). Endüstriyel üretimde ortalama randıman değerlerinin Yalova-12 soğan çeşidi temel alındığında \%8.00 (1/12.50) olduğu tespit edilmiştir. Laboratuvarımızda yaptı̆̆ımı denemelerde kurutma verimi değerleri (\%8.50-11.22) kurutma metoduna ve ön işleme bağlı olarak 1.4 katına kadar geliştirilmiştir.

Kurutmanın ticari kabul edilebilirliği için denemelerde kurutma veriminin tespitine yönelik analizler yapılmıştır. Kurutma veriminin belirlenmesinde 5 farklı ön işlem uygulanarak kabin kurutucuda kurutulan soğanlar değerlendirilmiştir. En yüksek verim tuzlu su uygulaması ile kurutulan örneklerde \%11.20 olarak belirlenmiştir. Diğer uygulamalardaki verimler ise sırasıyla çeşme suyu \%10.30, maltodekstrin \%9.80, ön işlemsiz \%9.40, patates nişastası ise \%7.90 olarak tespit edilmiştir. Kurutma metotlarının verim üzerine etkisi incelendiğinde; ön işlem uygulanmadan nem içeriği \%8.00-10.00 seviyelerine indirilen soğanlarda genel olarak kurutma veriminin \%8.50 - 9.50 aralığında olduğu ölçülmüştür.

\section{Kurutulmuş soğanların rehidrasyon kapasitesi}

Kurutulmuş bir meyve-sebze ürününde aranan en önemli özellik suda tutulduğunda taze halinde içerdiği su miktarına en yakın oranda su alarak eski haline ve şekline dönebilmesidir. Kurutulmuş bir ürünün rehidrasyon yeteneği, onun suda belli koşullarda ıslatılması sonucunda kazandığı su miktarı ile ölçülür. Ancak rehidrasyon sırasındaki koşullar, özellikle suyun sıcaklığı ve süresi, rehidrasyon yeteneği üzerinde son derece etkilidir (Cemeroğlu, 2004). Yapılan çalışmalar sonucunda soğan örneklerinin rehidrasyon kapasitesinde görülen değişimler ilgili grafiklerde gösterilmiştir (Şekil 1-5).

Ön işlem uygulanmadan açıkta kurutulan soğanlarda rehidrasyon kapasitesi $5.07 \pm 0.20$ iken tuzlu su ön işlemi uygulanarak açıkta kurutulan soğanlarda rehidrasyon kapasitesi $5.36 \pm 0.40$ 'e ulaşarak açıkta kurutulan ön işlem uygulanmış ürünler arasındaki en yüksek rehidrasyon kapasitesi elde edilmiştir. Pawar ve ark. (1988), güneş enerjili kurutucuda kurutulan tuz ön işlemli beyaz soğanların rehidrasyon kapasitelerinde çok az bir azalış olduğunu belirtmişlerdir. Bu araştırma kapsamında da ölçülen güneş enerjili kurutucuda kurutulan tuzlu su ön işlemli soğanların rehidrasyon kapasitesinde de benzer bir durum söz konusudur.

Endüstriyel üretimde ortalama rehidrasyon kapasitesi değerlerinin 3.5 civarında olduğu laboratuvar analizlerinde ortaya konulmuştur. Rehidrasyon kapasitesi 3.5 civarinda olan örnekler ortalama 5 TL (2013 yılı değerleri) olarak fiyatlandırımaktadır ve bu değer rehidrasyon kapasitesi 6 olan örneklerde 6 TL ve 8 olan örneklerde 7 TL olarak gerçekleşmektedir. Dolayısıyla rehidrasyon kapasitesindeki bu gelişmeler işlenmiş ürünlerin değerinin \%40 düzeyinde artışını sağlamaktadır.

Ön işlem uygulanmadan güneş enerjili kurutucuda kurutulan soğanlarda rehidrasyon kapasitesi $5.45 \pm 0.30$ iken maltodekstrin ön işlemi uygulanarak kurutulan soğanlarda rehidrasyon kapasitesi $5.74 \pm 0.20$ 'ye ulaşarak güneş enerjili sistemde kurutulan ve tüm ön işlem uygulamış örnekler arasında en yüksek rehidrasyon kapasitesine ulaşmıştır. Benzer 
şekillerde ön işlem uygulanmadan kabin kurutucuda kurutulan soğanlarda rehidrasyon kapasitesi $5.50 \pm 0.20$ iken, patates nişastası ön işlemi uygulanarak kurutulan soğanlarda rehidrasyon kapasitesi $5.94 \pm 0.40$ 'e ulaşarak kabin kurutucuda elde edilen rehidrasyon kapasitesi en yüksek ürünler olmuştur. Vakum kurutucuda ön işlem uygulanmadan kurutulan soğanlarda rehidrasyon kapasitesi $5.83 \pm 0.40$ iken çeşme suyu ön işlemi uygulanarak kurutulan soğanlarda rehidrasyon kapasitesi $6.69 \pm 0.70$ 'a ulaşarak vakum kurutucuda kurutulan tüm örnekler içerisindeki en yüksek rehidrasyon kapasitesi olarak belirlenmiş̧ir. Dondurarak kurutucuda ön işlem uygulanmadan kurutulan soğanlarda rehidrasyon kapasitesi $6.92 \pm 0.40$ iken çeşme suyu ön işlemi uygulanarak kurutulan soğanlarda rehidrasyon kapasitesi $7.94 \pm 0.50$ 'e ulaşarak dondurarak kurutucuda kurutulan tüm örnekler arasında en yüksek rehidrasyon kapasitesi tespit edilmiştir (Şekil 1-5). Bu değer aynı zamanda yapılan tüm ön işlem ve farklı kurutma metotları uygulamaları arasında kurutulmuş soğanlara kazandırılan en yüksek rehidrasyon kapasitesi olarak belirlenmiştir. Bunların yanı sıra en kısa sürede kurutma işlemi vakum kurutucu ve dondurarak kurutucuda gerçekleşmiştir. Vakum kurutucuda kurutma işlemi uygulanan ön işleme bağlı olarak 10-27 saat arasında tamamlanmıştır, dondurarak kurutulan soğanlarda ise işlem 24 saatte tamamlanmıştır (Çizelge 3).

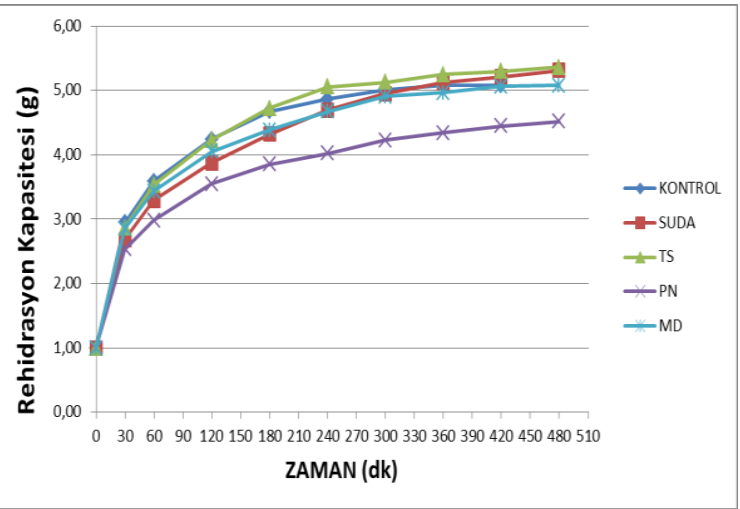

Şekil 1. Açıkta kurutulmuş soğanların rehidrasyon kapasiteleri

Figure 1. Rehydration capacity of open-air dried onions

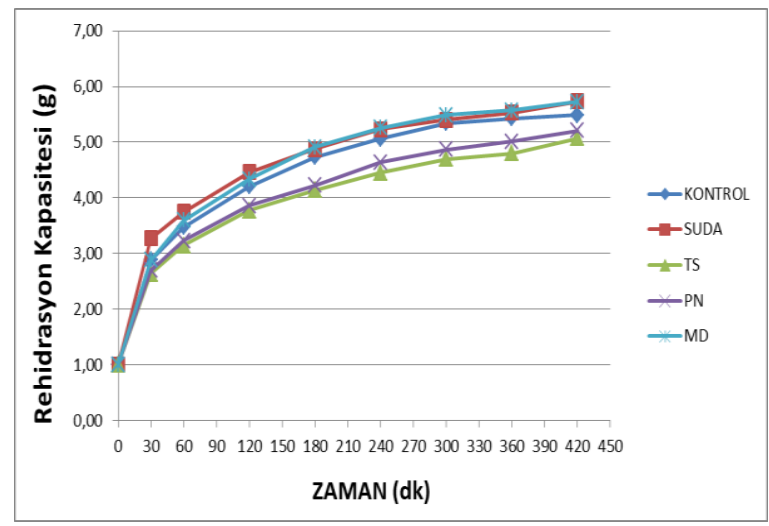

Şekil 2: Güneş enerjili sistemle kurutulmuş soğanların rehidrasyon kapasiteleri

Figure 2. Rehydration capacity of solar dried onions

Çizelge 3. Farklı ön işlem ve kurutma metotları uygulanan soğanların kuruma süreleri (saat) Table 3. Drying time (hour) of onion samples applied different pretreatments and drying methods

\begin{tabular}{lccccc}
\hline $\begin{array}{l}\text { Kurutma } \\
\text { Metodu }\end{array}$ & $\begin{array}{c}\text { Ön İşlemsiz } \\
\text { Untreated }\end{array}$ & $\begin{array}{c}\text { Patates Nişastası } \\
\text { Potato starch }\end{array}$ & $\begin{array}{c}\text { Tuzlu Su } \\
\text { Salted water }\end{array}$ & $\begin{array}{c}\text { Çeşme Suyu } \\
\text { Tap water }\end{array}$ & $\begin{array}{c}\text { Malto-dekstrin } \\
\text { Maltodextrin }\end{array}$ \\
\hline Kabin & 25 & 28 & 29 & 28 & 36 \\
Vakum & 10 & 11 & 27 & 21 & 18 \\
Açıkta & 110 & 44 & 106 & 84 & 84 \\
Güneş Enerili & 85 & 60 & 76 & 84 & 76 \\
Dondurarak & 24 & 24 & 24 & 24 & 24 \\
\hline
\end{tabular}




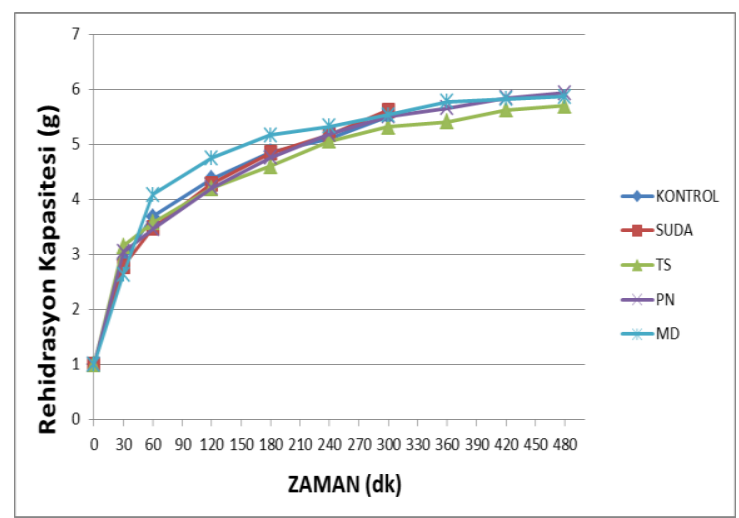

Şekil 3. Kabinde kurutulmuş soğanların rehidrasyon kapasiteleri

Figure 3. Rehydration capacity of cabinet dried onions

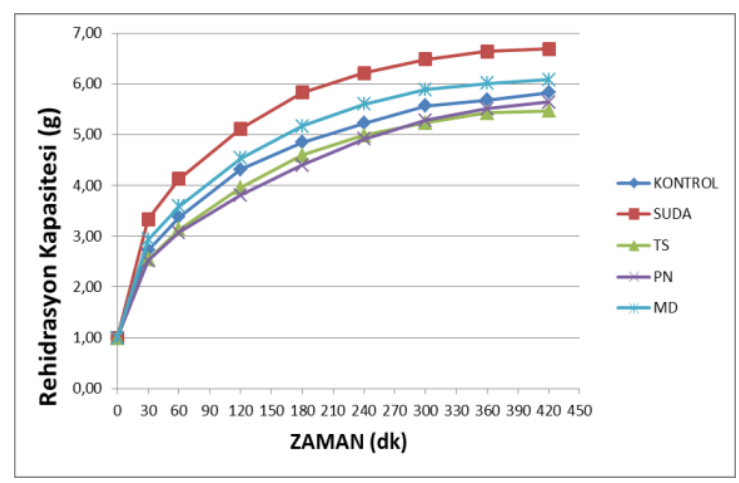

Şekil 4. Vakumda kurutulmuş soğanların rehidrasyon kapasiteleri

Figure 4. Rehydration capacity of onions dried in vacuum oven

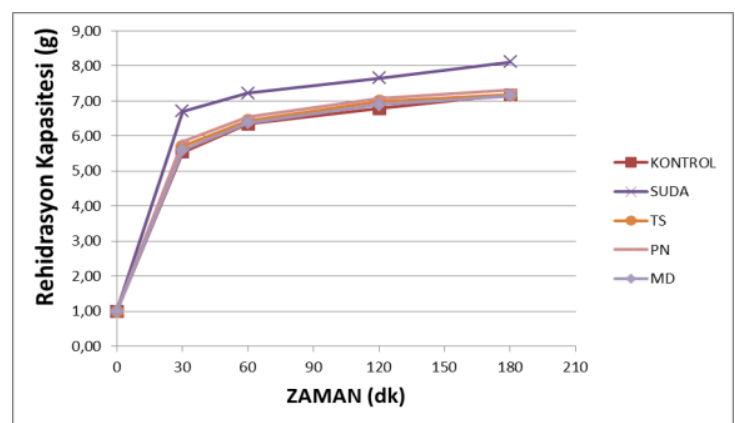

Şekil 5. Dondurarak kurutulmuş soğanların rehidrasyon kapasiteleri

Figure 5. Rehydration capacity of freeze dried onions
Kurutulmuş soğanların duyusal analizi

Yapılan duyusal analiz sonucunda kurutulmuş soğanlara uygulanan farklı kurutma yöntemleri ve farklı ön işlemler tüketici beğenisi açısından değerlendirilmiştir. $\mathrm{Bu}$ değerlendirmeler soğanların genel görünüşleri ve doğrudan tüketilmesi (çerez, atıştırmalık vb.) durumunda belirlenen değerlerdir.

Duyusal analizler sonucunda elde edilen veriler incelendiğinde farklı kurutma yöntemleri uygulanan soğanlarda en yüksek puan değerleri renk olarak dondurarak ve güneş enerjili kurutucuda; en iyi gevreklik olarak açıkta, vakum kurutucuda ve kabin kurutucuda; en iyi koku olarak dondurarak kurutucuda; en iyi lezzet olarak ise vakum kurutucu ve dondurarak kurutucularda kurutulmuş soğanlarda tespit edilmiştir. Genel izlenime bakıldığında ise en yüksek puanı kabin kurutucuda dehidre edilen soğanların aldığı, dondurarak ve açıkta kurutulan örneklerin kabin kurutucudan elde edilen örnekleri izlediği gözlenmiştir. Farklı ön işlemler uygulanarak kurutulan soğanlar incelendiğinde ise en yüksek renk ve koku puanlarını çeşme suyu ve ön işlemsiz örneklerin; gevreklik olarak maltodekstrin ve tuzlu su ön işlemleri en yüksek puanları almıştır. Genel izlenime bakıldığında ise en yüksek puanları ön işlem uygulanmayan ve tuzlu su uygulaması almıştır (Çizelge 4 ve 5 ). 
Çizelge 4. Farklı tekniklerle kurutulmuş soğanların duyusal değerlendirilmesi Table 4. Sensory analysis of onions dried using different methods

\begin{tabular}{lccccc}
\hline Kurutma Yöntemleri & $\begin{array}{c}\text { Renk } \\
\text { Color }\end{array}$ & $\begin{array}{c}\text { Gevreklik } \\
\text { Tenderness }\end{array}$ & $\begin{array}{c}\text { Koku } \\
\text { Odor }\end{array}$ & $\begin{array}{c}\text { Lezzet } \\
\text { Taste }\end{array}$ & $\begin{array}{c}\text { Genel İzlenim } \\
\text { General impression }\end{array}$ \\
\hline Kabin & $5.10 \pm 0.10$ & $7.50 \pm 0.40$ & $5.90 \pm 0.30$ & $6.90 \pm 0.20$ & $6.90 \pm 0.40$ \\
Vakum & $4.90 \pm 0.30$ & $7.80 \pm 0.30$ & $5.80 \pm 0.30$ & $7.10 \pm 0.10$ & $6.30 \pm 0.20$ \\
Dondurarak kurutma & $7.60 \pm 0.30$ & $5.20 \pm 0.50$ & $7.40 \pm 0.40$ & $7.50 \pm 0.30$ & $6.70 \pm 0.20$ \\
Güneş enerjili & $7.00 \pm 0.10$ & $2.70 \pm 0.60$ & $5.20 \pm 0.20$ & $4.50 \pm 0.20$ & $4.50 \pm 0.40$ \\
Açık hava & $4.80 \pm 0.10$ & $7.80 \pm 0.20$ & $5.70 \pm 0.30$ & $6.30 \pm 0.20$ & $6.40 \pm 0.30$ \\
\hline Genel Ortalama & $5.90 \pm 0.20$ & $6.20 \pm 0.40$ & $6.00 \pm 0.30$ & $6.50 \pm 0.20$ & $6.20 \pm 0.30$ \\
\hline
\end{tabular}

Çizelge 5: Ön İşlem uygulanmış soğanların duyusal değerlendirilmesi

Table 5. Sensory analysis of pre-treated onions

\begin{tabular}{lccccc}
\hline $\begin{array}{c}\text { Ön İşlemler } \\
\text { Pret-reatments }\end{array}$ & $\begin{array}{c}\text { Renk } \\
\text { Color }\end{array}$ & $\begin{array}{c}\text { Gevreklik } \\
\text { Tenderness }\end{array}$ & $\begin{array}{c}\text { Koku } \\
\text { Odor }\end{array}$ & $\begin{array}{c}\text { Lezzet } \\
\text { Taste }\end{array}$ & $\begin{array}{c}\text { Genel İzlenim } \\
\text { General impression }\end{array}$ \\
\hline Tuzlu Su & $5.60 \pm 0.20$ & $8.20 \pm 0.20$ & $6.50 \pm 0.20$ & $7.00 \pm 0.20$ & $6.40 \pm 0.40$ \\
Patates Nişastası & $4.90 \pm 0.10$ & $8.00 \pm 0.20$ & $5.90 \pm 0.20$ & $6.50 \pm 0.10$ & $6.30 \pm 0.20$ \\
Maltodekstrin & $4.30 \pm 0.10$ & $8.50 \pm 0.20$ & $5.90 \pm 0.10$ & $5.60 \pm 0.20$ & $5.00 \pm 0.30$ \\
Çeşme Suyu & $8.00 \pm 0.20$ & $6.10 \pm 0.30$ & $7.20 \pm 0.10$ & $6.40 \pm 0.10$ & $5.60 \pm 0.40$ \\
Kontrol & $7.00 \pm 0.10$ & $6.00 \pm 0.10$ & $7.40 \pm 0.10$ & $6.80 \pm 0.30$ & $6.50 \pm 0.20$ \\
\hline Genel Ortalama & $6.00 \pm 0.20$ & $7.30 \pm 0.20$ & $6.60 \pm 0.10$ & $6.50 \pm 0.20$ & $5.90 \pm 0.30$ \\
\hline
\end{tabular}

\section{Sonuçlar}

Kurutma ile soğandaki mevcut su onun bozulmasına imkân vermeyecek bir seviyeye indirildiği için kesin bir muhafaza sağlanmıştır. Aynı zamanda soğanın besin ögeleri olarak da yoğunlaştırılmış bir özellik kazandırılmıştır. Ambalajlama ve taşıma maliyetleri de azaltılarak kullanım alanı artırımaktadır. Örneğin soğanlar hazır çorba üretiminde temel hammaddelerden birisidir. Bu yüzden soğanların kurutularak da değerlendirilmesi ülkemiz tarım ve gıda sanayi için elzem bir işlemdir. Endüstriyel kurutulmuş soğan üretiminde daha iyiye ulaşmak için diğer kriterlerin yanında kurutma verimi ve rehidrasyon yeteneğinin artırılması öncelikli temel amaçlardandır. $\mathrm{Bu}$ kapsamda yaptığımız çalışmalarda aşağıda belirttiğimiz sonuçlar elde edilmiştir.

Elde edilen verilere göre renk değerleri olarak tüketici beğenisine en çok hitap eden örneklerin dondurarak kurutma ile elde edilen soğanlar olduğu sonucuna varılmıştır. Bu sonuç hem duyusal analizler hem de enstrumental renk analizi sistemi kullanılarak teyit edilmiştir. Örneklerin L* değerleri parlak ve açık rengi işaret etmektedir ve bu değer dondurarak kurutulan örneklerde $83.00 \pm 20$ değerleri seviyelerinde ölçülmüştür. Örneklerin $L^{*}$ renk değerleri karşılaştırıldığında diğer kurutma metotlarından elde edilen örneklerde bu değerin 55.00-65.00 bandında olduğu ve dolayısıyla dondurularak kurutulmuş örneklerin $L^{*}$ değerinin diğer örneklerin $L^{*}$ değerlerinden yüksek olduğu tespit edilmiştir. 
Bu durum dondurularak kurutulan soğanların renk değerinin korunduğunu göstermektedir. Örneklerin renk kalitelerinin karşılaştırılmasında kullanılan diğer bir ölçütte sahip oldukları $b^{*}$ değerleridir. Kaliteli kurutulmuş soğanlarda bu değerin mümkün olduğunca düşük olması arzu edilmektedir. Örnekler b* değerleri açısından kıyaslandığında en düşük değer dondurularak kurutulan ürünlerde tespit edilmiş $(13.00 \pm 1.00)$ ve bu soğanların analiz edilen örnekler arasında en gelişmiş renk kalite özelliklerine sahip oldukları belirlenmiştir. Aletsel renk ölçüm değerlerini duyusal analizler de teyit etmiş ve panelistlerin değerlendirmelerine göre de dondurularak kurutulmuş ürünlerin en yüksek renk beğeni değerlerine sahip oldukları tespit edilmiştir.

Bu çalışmanın kapsamında elde edilen en önemli veriler örneklerin sahip oldukları rehidrasyon kapasitelerine dairdir. Çalışmanın amacında da belirtildiği gibi temel hedef rehidrasyon kapasitesi daha yüksek olan kurutulmuş soğanlar elde edilmesidir. Zira rehidrasyon kapasitesi ürünün fiyatlandırılmasını doğrudan etkileyen kıstasların başındadır. Elde edilen sonuçlara göre en gelişmiş rehidrasyon kapasitesi dondurularak kurutulmuş soğanlarda tespit edilmiştir. Dondurularak kurutulan soğanlarda rehidrasyon kapasitesi $7.94 \pm 0.5$ düzeyine kadar yükselmiştir. Dondurarak kurutmanın yanı sıra diğer uygulanan kurutma metotlarında da kurutulmuş ürünlerin rehidrasyon kapasitelerinin geliştirilmesi bağlamında olumlu sonuçlar elde edilmiştir. Vakum kurutucuda kurutulan ürünlerde rehidrasyon kapasitesi uygulanan ön işleme bağlı olarak $6.69 \pm 0.7$ seviyelerine, kabin kurutucuda işlenen ürünlerde
$5.94 \pm 0.4$ 'e, güneş enerjili kurutucuda kurutulan ürünlerde $5.74 \pm 0.7$ 'e ve açıkta kurutulan soğanlarda $5.36 \pm 0.3$ seviyelerine ulaşmıştır. Elde edilen verilere göre güneş enerjili kurutucularda kurutulan örnekler dahil olmak üzere kurutulmuş soğanların rehidrasyon kapasiteleri tatmin edici düzeylere yükseltilmiştir. Şanlıurfa ilinin sahip olduğu coğrafi ve iklim koşulları dikkate alındığında uygun şekilde yapılan açıkta ve güneş enerjili kurutma işlemlerinin bölgedeki meyve-sebze kurutma faaliyetlerinde kullanılabilir mahiyette olduğu sonucu ortaya çıkmıştır. Bunun ötesinde yapay kurutma metotlarından kabinde kurutma ve vakumlu fırında kurutma tekniklerinin de önemli ölçüde uygulanabilir nitelikte oldukları tespit edilmiştir. Özellikle vakumlu fırın kurutucuda işlenen soğanların hem duyusal analizlerden olumlu sonuçlar almaları, hem rehidrasyon kapasitelerinin yüksek olması hem de kurutma işleminin diğer metotlara göreceli olarak daha kısa sürede tamamlanıyor olması bu kurutma metodunun kullanımının endüstriye tavsiye edilebileceğini ortaya koymaktadır. Rehidrasyon kapasitesi açısından verileri inceleyecek olursak dondurarak kurutulmuş soğanların suya batırıldıkları ilk yarım saat içerisinde ağırlıklarının 6 katı oranında yapılarına su aldıkları ve bu kısa süre içerisinde rehidrasyon kapasitelerinin 7 seviyesine çıktığı ve 3 saat içerisinde maksimum rehidrasyon kapasitelerine ulaştıkları tespit edilmiştir. Bu durum gıda sektörünün aradığı bir diğer önemi özellik olarak ön plana çıkmıştır zira ticari olarak kısa zaman içerisinde yüksek miktarda su çekebilen ürünler daha fazla talep görmekte ve yüksek rakamlarla fiyatlandırılmaktadır. Hem üretim 
randımanındaki artış hem de ürünün fiyatlandırılmasındaki bu artış kuru soğan üretimini ve ticaretini konu alan işletmelerin karlılığında önemli derecede iyileşmeye yol açacaktır.

Çalışma dahilinde yürütülen ön işlem uygulamalarının doğrudan son ürün rehidrasyon kapasitesine herhangi bir kayda değer etkisi tespit edilememiştir. Ancak soğanların çeşme suyuna daldırılmaları kimi durumlarda olumlu katkı sağlamıştır. Çeşme suyu ön işlemi maliyeti düşük olduğu için üreticilere ekonomik açıdan kazanç sağlayabilmektedir. Tüketicilerin damak tadı dikkate alındığında duyusal analiz sonucunda en çok tercih edilen ön işlemin ise tuzlu su olduğu gözlenmiştir. Bunun yanı sıra kurutma işleminden önce tuzlu suya daldırılan soğanların duyusal değerlendirme de yer alan panelistler tarafından lezzet açısından en yüksek skorlarla beğenilmesi ve atıştırmalık cips kapsamında kabul görmesi yeni bir ürün geliştirilmesine ön ayak olabilecek niteliktedir. Bu sayede katma değeri daha da geliştirilmiş bir işlenmiş gıda maddesi üretimi mümkün olabilecektir.

\section{Kaynaklar}

Altuğ, T., 1993. Duyusal Test Teknikleri. E. Ü. Mühendislik Fakültesi Ders Kitapları, No: 28, İzmir, 56.

Amerine, A.M, Pongborn, R.M, Roessler, E.B., 1965. Principles of Sensory Evaluation of Food. Academic Pres. New-York

Anonim, 2016. http://mtntohum.com/soganhakkinda-bilgiler.html

AOAC, 1985. Official Methods of Analysis (13th Ed.). Washington, DC. Association of Official Analytical Chemists.

AOAC, 2000. Official Methods of Analysis (17th Ed.). Method 934.01, Washington, DC. Association of Official Analytical Chemists.
Arslan, D. and Özcan, M.M., 2010, Study the effect of sun, oven and microvave drying on quality of onion slices. LWT-Food Science and Technology, 43,1121-1127.

Cemeroğlu, B., 2004. Meyve ve Sebze İşleme Teknolojisi 2. Cilt 2. Baskı, Gıda Teknolojisi Derneği yayınları, 549-550.

Gökçe, A.F., Kaya, C., Serçe, S., and Özgen, M., 2010. Effect of Scale Color on the Antioxidant Capacity of Onions. Scientia Horticulturae, 123, 431-435.

Gould, A.W., 1977. Food Quality Assurance. The AVI Publ. Co. Inc. USA. 314p.

Kaymak-Ertekin, F., and Gedik, A., 2005. Kinetic Modelling of Quality Deterioration in Onions During Drying and Storage. Journal of Food Engineering, 68, 443-453.

Krokida, M.K., Oreopoulou, V., Maroulis, Z.B., and Kouris, D.M., 2001. Colour Changes During Deep Fat Frying. Journal of Food Engineering, 48:219-225.

Kumar, A., and Tiwari, G.N., 2007, Effect of mass on convective mass transfer coefficient dyring open sun and greenhouse drying of onion flakes. Journal of Food Engineering, 79,1337-1350.

Lewicki,P.P., and Witrowa-Rajchert,D.,1998. Rehydration Properties of Dried Onion. International Journal of food Properties. 1(3), 275-290.

Mc Guire, R.G., 1992. Reporting of Objective Color Measurements. HortScience, 27, 12541255.

Mitra, J., Shrivastava, S.L., and Rao, S.P., 2011. Vacuum Dehydration Kinetics of Onion Slices. Food and Bioproducts Processing, 89, 1-9.

Mota, C.L., Luciano, C., Dias, A., Barroca, M.J., and Guine, R.P.F., 2010. Convection Drying of Onion: Kinetics and Nutritional Evaluation. Food and Bioproducts Processing, 88, 115123.

Pawar, V.N., Singh, N.I., Dev, D.K., Kulkarni, D.N., and Ingle, U.M., 1988. Solar Drying of White Onion Flakes. Ind Food Packer, 42(1), 15-28.

Rapusas, R.S. and Driscoll, R.H., 1995. The thinlayer Drying characteristics of white onion slices. Drying Technology, 13 (3-4), 19051931. 
Roldan-Marin, E., Sanchez-Moreno, C., Lloria, R., Ancos, B., and Cano, M.P., 2009. Onion High-Pressure Processing: Flavonol Content and Antioxidant Activity. LWTFood Science and Technology, 42, 835-841.

Scott, W.J. 1957. Water relations of food spoilage microorganisms. Advanced Food Research, 7, 83-127.

Vardin, H. ve Binici, T. ,2006.Güneş Enerjisi ile Kurutulmuş Gıda Ürünleri ve Pazar Potansiyeli, GAP-GIDEM (AB destekliGirişimci Destekleme Merkezi) Yayınları. Proje Yönetim ve Koordinasyon Birimi, Nurol Matbaacılık A.Ş. Ankara 